Communication

\title{
Building on Vietnam's Recent COVID-19 Success: A Job-Focused Analysis of Individual Assessments on Their Finance and the Economy
}

\author{
Hai-Anh H. Dang ${ }^{1}\left(\mathbb{D}\right.$, Long T. Giang ${ }^{2} \mathbb{D}$ and Minh N. N. Do ${ }^{3, * \mathbb{D}}$ \\ 1 Data Production and Methods Unit, Development Data Group, World Bank, 1818 H St NW, \\ Washington, DC 20433, USA; hdang@worldbank.org \\ 2 Faculty of Economics, National Economics University (NEU), Hanoi 11616, Vietnam; longgt@neu.edu.vn \\ 3 Finance and Banking Department, University of Economics and Business-Vietnam National University, \\ 144 Xuan Thuy Str, Cau Giay Dist, Hanoi 10000, Vietnam \\ * Correspondence: minh.nn.do@gmail.com
}

Citation: Dang, H.-A.H.; Giang, L.T.; Do, M.N.N. Building on Vietnam's Recent COVID-19 Success: A

Job-Focused Analysis of Individual Assessments on Their Finance and the Economy. Sustainability 2021, 13, 10664. https://doi.org/10.3390/ su131910664

Academic Editor: Antonella Petrillo

Received: 17 June 2021

Accepted: 13 September 2021

Published: 25 September 2021

Publisher's Note: MDPI stays neutral with regard to jurisdictional claims in published maps and institutional affiliations.

Copyright: () 2021 by the authors. Licensee MDPI, Basel, Switzerland. This article is an open access article distributed under the terms and conditions of the Creative Commons Attribution (CC BY) license (https:// creativecommons.org/licenses/by/ $4.0 /)$.

\begin{abstract}
Despite the harmful effects of the COVID-19 pandemic on income and employment loss around the globe, hardly any formal study exists on household finance and future economic expectations in poorer countries. We offer an early study that aims to fill this gap from the labor market angle. We implemented and analyzed a new web-based rapid assessment survey immediately after the removal of lockdown measures in Vietnam, a low-middle income country that has received widespread recognition for its successful fight against the pandemic. We find that having a job is strongly and positively associated with better finance and more income and savings, as well as more optimism about the resilience of the economy. Further disaggregating employment along the security dimension into different types of jobs such as self-employment and jobs with permanent and short-term contracts, we find those with permanent job contracts to have fewer job worries and better assessments for the economy. Individuals with good health tend to have more positive evaluations for their current and future finance, but there is mixed evidence for those with higher educational levels. These findings are relevant for the ongoing fight against the pandemic and post-outbreak labor policies, especially in a developing country context.
\end{abstract}

Keywords: COVID-19; recession; labor market; wage work; household finance; Vietnam

JEL Classification: I1; I3; J01; J08; O1

\section{Introduction}

The COVID-19 outbreak has resulted in income and employment loss in many rich and poor countries around the world. For instance, as much as 18 percent and 15 percent of the respondents in a recent survey report losing their job from late March to early April 2020 in the U.S. and the U.K., respectively [1]. This could result in lower expectations about one's future economic prospects.

We offer a new study on the short-term impacts of COVID-19-induced lockdown measures on household financial situations and expectations for the future in Vietnam, a lower-middle income country. We investigate six key policy questions: First, for individuals who are affected by the pandemic lockdown measures, what is the relationship between their employment (and other) characteristics and their finance, income, and savings? Second, what are the expectations for their finance after the outbreak is over? Third, do those with job security worry less about their financial situation in the future? Fourth, what are their expectations for the general economy? Fifth, would those with job security have higher expectations? Finally, are they also more optimistic about the economy's ability to recover? 
These questions have much relevance for economic policies, both during and after the pandemic, especially regarding the labor market for Vietnam and other similar developing country contexts. More generally, they are also relevant to the country's efforts to meet Sustainable Development Goal (SDG) number 8 on promoting productive employment and decent work, SDG number 1 on reducing poverty, and SDG number 5 on achieving gender equality.

Vietnam offers a remarkable case study as a country that has successfully fought against COVID-19. As yet, despite a population of about 97 million people and its shared border with China - the epicenter of the pandemic - Vietnam has recorded around 150,000 infected cases and slightly more than 1300 deaths by the end of July 2021 [2]. The country's successful measures, such as prompt responses, aggressive testing and quarantining, and effective government communications, have been widely discussed both in the academic literature [3-8], and the international media including the Financial Times [9], the Wall Street Journal [10], and the Project Syndicate [11]. However, like most countries around the world, Vietnam has also suffered from lockdown measures that have negatively impacted its economy, particularly the labor market $[12,13]$. One key challenge is thus for the country to build on this success to help the economy recover and continue its pre-outbreak economic growth.

Analyzing just-in-time data from a web-based rapid assessment survey that we implemented immediately after the removal of lockdown measures in Vietnam in late April to early May 2020, we find that having a job is positively and statistically significantly associated with better finance and more income and savings. Having a job is, unsurprisingly, negatively associated with worries about job loss in the future and positively associated with more optimism about the resilience of the economy. Further disaggregating employment along the security dimension into different types of jobs such as self-employment (i.e., including business owners and family workers) and working for wages (i.e., having a permanent job contract vs. having a short-term job contract), we find these job types to exhibit differential and interesting relationships with financial outcomes.

In particular, being self-employed is less strongly associated with reduced job worries than working for wages. Individuals with a permanent job contract have fewer job worries and also have more positive assessments for the economy. Individuals in good health tend to have more positive evaluations for their current and future finance. There is mixed evidence for those with higher educational levels. Some indicative evidence suggests that women in Vietnam tend to have more pessimistic expectations for their future financial situations. Put differently, vulnerable workers (including those with lower educational levels, in worse health, or without a labor contract) are particularly at economic risks caused by the COVID-19 pandemic. We also find a positive correlation between the number of workers in a province and the pandemic death rates and infection rates.

Our study adds to the barely existent literature on the impacts of COVID-19 on individual economic expectations through a labor market angle, particularly in a poorer country context. The effects of the outbreak can vary significantly between richer and poorer countries because of their systematic differences in labor market institutions. Yet, despite a growing literature on various aspects of the harmful effects of the pandemic for richer countries, hardly any study exists on household finance and economic expectations for the future in a developing country context.

This paper consists of six sections. We briefly review the literature in the next section before discussing the survey data and the analytical framework in Section 3. We offer in Section 4 the estimation results on the profiles of individuals and factors that are associated with their current and expected finance situations. We provide further discussion of our results and policy recommendations in Section 5 and finally conclude in Section 6 .

\section{Literature Review}

It is well known that perceptions and expectations about the macroeconomic environment substantially shape households' economic decisions [14-19], even during infrequent 
major events $[20,21]$. Indeed, individuals in the U.S. are concerned about the effects of COVID-19 on the economy, their health, and their personal finances [22,23]. Households living in counties that went into lockdown earlier expect the unemployment rate over the next twelve months to be 13 percentage points higher and continue to expect higher unemployment at horizons of three to five years [14]. On average, an individual's perceived probability of losing their job within the next few months reaches 35 percent and 31 percent in the U.S. and the U.K., respectively [24].

Furthermore, gender gaps are exacerbated during the pandemic. Examining data from China, Italy, Japan, South Korea, the U.K, and the U.S., [25] we find that women are 24 percent more likely to permanently lose their job than men, and women also expect their labor income to fall by 50 percent more than men because of the outbreak. Yet, the existing studies in richer countries tend to examine household (individual) expectations through other angles such as wealth shocks or residence in counties under lockdown rather than the labor market viewpoint (see, e.g., [14,26-28]). A recent exception is [29], who find that in 18 out of 28 advanced economies women's employment fell more than men's during the pandemic, and in 19 out of 28 countries women experienced a larger decline in hours worked.

Regarding poorer countries, very few studies exist on individual economic expectations, especially through a labor market angle. Some limited survey evidence for poorer countries has emerged, but mostly from NGOs (e.g., [30]) or private consulting firms such as McKinsey and Company [31]. See also [26] and [27] for reviews of recent studies on the general impacts of the pandemic. Reference [32] analyzed the effects of providing information on others' beliefs on respondents' own beliefs and consumer sentiment in a randomized control trial setting in Thailand and Vietnam. They found that the information treatments positively affect consumer sentiment only in Vietnam, especially when the information goes against respondents' prior beliefs. Reference [33] mostly focus on the impacts of whether knowledge of someone infected with COVID-19 changes Chinese households' investment decisions.

\section{Materials and Methods}

\subsection{Data}

We conducted a new web-based survey immediately after Vietnam relaxed its lockdown measure during the two weeks of from 26 April to 9 May 2020. We obtained approval to implement the survey from the Institutional Review Board (IRB) at the Institute of Social and Medical Studies (ISMS), which is registered with the Office for Human Research Protections of the U.S. Department of Health (IRB No.IORG0006663; FWA 00016762). On the first page of the online questionnaire, we provided a consent form for the respondents. This form explicitly indicated that the respondent responds to the questions with willingness and they could stop or exit the survey any time. This survey was implemented in collaboration with a research team at ISMS in Hanoi, Vietnam. The survey consists of four sections with 46 questions, which collect data on individual characteristics (such as age, sex, job, education, and health status), their household financial situation, their expectations and concerns about work, household finance, and the national economy, and their evaluations about the effectiveness of the government's policies against COVID-19. We focus in this paper on the data related to jobs and economic outcomes, and we provide in Appendix A the English translation of the part of the survey questionnaire that we analyze. To our knowledge, this is the first survey that has rapidly collected data on Vietnamese individuals' finance and economic expectations after the country first lifted its pandemic-induced lockdown measures.

We employed the convenience (snowball) sampling method and invited individuals in our network to participate in the survey. We contacted these individuals through institutional and personal emails and through popular social media platforms in Vietnam such as Facebook, Viber, and Zalo. The advantages of online surveys are numerous, including flexibility, speedy data collection, ease of data entry and analysis, and cost-effectiveness, 
but these surveys may suffer from representativeness or selection bias [34]. To address these limitations, various standard techniques can be used such as pre-survey designs (including randomization or quotas) or post-survey adjustments (including imputation or reweighting) [35,36]. Despite its limitations, given the timeliness and low costs of data collection, the convenience sampling method has been widely used to obtain rapidly collected data for timely assessments of the impacts of COVID-19.

As an example, reviewing early medical studies on the pandemic, [37] observe that many rapid pilot studies on serosurveillance, which use unstructured or convenience sampling strategies, have nonetheless yielded important, early, and actionable findings. For further comparison on the other key features of online surveys as suggested in [38], we show in Table 1 [39-43] a sample of five recently published studies that employ online surveys and the convenience sampling method to investigate the impacts of COVID-19. These studies cover various subjects such as finance, expectations about own career, parenting practices, and perception of government responses. They are published in different journals, with three placed in Quartile 1, one in Quartile 2, and one in Quartile 4 of Scimago journal ranks in 2021. Notably, no studies discuss whether they receive internal review board (IRB) approval for the survey. Only two studies pilot the questionnaire before implementing the survey [41,42] and another two studies make some post-survey weighting adjustments [42,43]. Three studies describe cleaning the data to remove incomplete questionnaires [40-42].

We follow best-practice advice with implementing all the steps of an online survey [38]. This includes obtaining IRB approval, ensuring data protection and confidentiality, piloting the questionnaire, removing incomplete data, and providing post-survey bias corrections. In particular, we received 677 respondents for our survey in total. After checking the data, however, we removed 24 respondents due to their incomplete answers to the survey questionnaire. This results in the final sample for analysis of 653 respondents.

Following [35]'s suggestions, we employ a two-pronged approach to address potential sampling bias resulting from the convenience sampling method. First, we reweight the survey using the gender and age variables according to the Labor Force Survey (LFS) in 2020. The LFS is annually conducted by Vietnam's General Statistical Office and offers nationally representative data on (un)employment characteristics for the country. We apply [44]'s Stata procedures to implement the modified chi-squared distance function for survey reweighting developed by [45]. Second, we will also compare the results in our study against those in studies for richer countries, where such similar studies are available, to provide further qualitative robustness checks.

Table 2 provides the descriptive statistics of all the variables. The age of the individuals in our sample averages 42 and ranges from 18 to 68 . Roughly half of them are female (51 percent), married (76 percent), live in urban areas ( 89 percent), and follow no religion (77 percent). In terms of education achievement, 32 percent of individuals have a college degree while 61 percent have a graduate degree (i.e., master's degree or higher levels). Around 56 percent of all individuals have a permanent job contract, and 15 percent have a short-term job contract (i.e., one that is less than 3 years). Only 11 percent of the survey respondents are self-employed. 
Table 1. A sample of recent studies that employ online surveys based on the convenience sampling method.

\begin{tabular}{|c|c|c|c|}
\hline No. & Study & Main Survey Features & Key Findings \\
\hline 1 & [39] (Q2) & $\begin{array}{l}\text { The online non-probabilistic survey was conducted } \\
\text { with the general population in the United Kingdom } \\
\text { between 18th and 20th March } 2020 \text { using the platform } \\
\text { Prolific and in Sweden between 7-23 April } 2020 \text { using } \\
\text { the panel provider Origo Group. Final sample: } 1000 \\
\text { persons in UK; } 1021 \text { persons in Sweden. }\end{array}$ & $\begin{array}{l}29 \% \text { of British respondents and } 7 \% \text { of } \\
\text { Swedish respondents believed that the } \\
\text { economic situation of their household will be } \\
\text { a lot worse in the future than it is now. More } \\
\text { respondents anticipated that the national and } \\
\text { global economic situation would be a lot } \\
\text { worse in the future than it is now. These } \\
\text { figures were, respectively, } 61.4 \% \text { and } 62.0 \% \\
\text { in the UK and } 36.2 \% \text { and } 47.0 \% \text { in Sweden. }\end{array}$ \\
\hline 2 & [40] (Q1) & $\begin{array}{l}\text { Families were recruited from child- and } \\
\text { family-serving agencies in the Rocky Mountain } \\
\text { region of the United States. They were informed } \\
\text { in advance to be interviewed by phone or email. } \\
\text { Parents (aged } 18 \text { years or older) with a child } \\
\text { (under 18) were provided an online survey link } \\
\text { that was administered via Qualtrics from } \\
21 \text { April } 2020 \text { to } 9 \text { May } 2020 . \\
183 \text { final parents with completed forms } \\
\text { (33 provided incomlete forms). }\end{array}$ & $\begin{array}{l}\text { - Parental support and perceived control } \\
\text { over the COVID-19 pandemic were } \\
\text { significantly and negatively associated } \\
\text { with perceived stress. } \\
\text { Perceived control over the pandemic } \\
\text { were significantly and negatively } \\
\text { associated with abuse potential. } \\
\text { Loss of employment or income and an } \\
\text { inability to provide for their family was } \\
\text { the most salient stressor. }\end{array}$ \\
\hline
\end{tabular}

- Two countries-Yemen and Saudi Arabia-were selected for the study. A mixture of purposive and snowball techniques facilitated to choose the respondents via email.

- $\quad$ A pilot examination with 20 academic residents from both countries was conducted to confirm the logical reliability, wording, meaning, and suitability of each question.

$3 \quad[41](\mathrm{Q} 4)$

$4 \quad[42](Q 1)$
- After the strict region-wide social distancing rules to cover the outbreak, 950 questionnaires were distributed through email one time to people from different sectors who had a job from 1 June to 30 July 2020. After data cleansing, a total of 307 respondents volunteered to participate in the survey as final sample.
Information collected on COVID-19 thought concern (9 items), employees' work performance (5 items), employees' background (6 items), feeling about job (5 items), work motivation (6 items), job satisfaction (6 items), psychological state of mind ( 2 items) and family commitment (3 items).
- Used a Qualtrics XM online survey (Qualtrics Survey Software) for reaching participants through social network posts for the general public (people aged $\geq 18$ years), which was based on the online survey method of nonprobability sampling.

- $\quad$ Survey was distributed to the public using three main social media platforms: Facebook, WhatsApp, and Instagram.

- Before the questionnaire was distributed, a content validation process was undertaken by performing a pilot study of 20 participants.

- 1348 people participated in the survey, but the final sample was 1056 participants.

- A weighting index was calculated to make the ethnicity distribution of the sample proportional to the general population distribution.
The study finds a significant difference in the personal risk perceptions between age groups, a significant positive correlation between overall risk perception and attitude toward crisis management, a significant positive correlation between overall risk perception and economic threat perception, a significant positive correlation between attitudes toward crisis management and compliance with behavioral guidelines, and a significant difference between participants who attributed the most credibility to different information sources and their attitudes toward crisis management. 
Table 1. Cont.

\begin{tabular}{|c|c|c|c|}
\hline No. & Study & Main Survey Features & Key Findings \\
\hline 5 & [43] (Q1) & $\begin{array}{l}\text { - The research was conducted in Flanders, the } \\
\text { largest of three Belgian regions. Research } \\
\text { population consisted of Flemish employees } \\
\text { under the age of } 65 \text { (the legal retirement age in } \\
\text { Belgium). } \\
\text { Web survey was conducted from Wednesday } \\
25 \text { March } 2020 \text { to Tuesday } 31 \text { March } 2020 \text { via a } \\
\text { link to the Qualtrics website. } \\
\text { Post-stratification entailed the selection of a } \\
\text { sub-sample of } 3821 \text { individuals resembling the } \\
\text { population of Flemish employees under } 65 \text { years } \\
\text { of age in terms of (i) gender, (ii) age, and (iii) } \\
\text { education level from the total sample of } \\
\text { 14,005 respondents. }\end{array}$ & $\begin{array}{l}\text { - } 21.1 \% \text { of the respondents are afraid of } \\
\text { losing their job due to the COVID-19 } \\
\text { crisis. About } 13.7 \% \text { fear that this will } \\
\text { even be the case before the end of the } \\
\text { year. } \\
\text { Women express a more pronounced } \\
\text { fear of job loss and a negative impact on } \\
\text { their careers while men are relatively } \\
\text { more worried about the number of } \\
\text { attractive vacancies. } \\
\text { Workers with a tertiary education } \\
\text { express less fear to miss out on a } \\
\text { promotion. }\end{array}$ \\
\hline
\end{tabular}

Note: Q no. represents the Scimago journal rankings (https:/ / www.scimagojr.com/index.php, accessed on 15 August 2021) for the journal that the study was published in.

Table 2. Descriptive statistics, Vietnam 2020.

\begin{tabular}{|c|c|c|c|c|c|}
\hline & $\begin{array}{l}\text { No. of } \\
\text { Observations }\end{array}$ & Mean & $\begin{array}{l}\text { Standard } \\
\text { Deviations }\end{array}$ & Min & $\operatorname{Max}$ \\
\hline \multicolumn{6}{|l|}{ Self-assessment on COVID-19 impact } \\
\hline Current financial situation & 653 & 3.14 & 0.89 & 1 & 5 \\
\hline Income change & 653 & 1.36 & 0.51 & 1 & 3 \\
\hline Saving change & 653 & 1.49 & 0.67 & 1 & 3 \\
\hline Expected financial situation during next 3 months & 653 & 3.05 & 0.91 & 1 & 5 \\
\hline Worry about own job & 653 & 1.95 & 0.68 & 1 & 3 \\
\hline $\begin{array}{l}\text { Expected resilience of the economy after the current } \\
\text { COVID-19 outbreak }\end{array}$ & 653 & 2.10 & 0.69 & 1 & 3 \\
\hline Expected changes to the economy during next 3 months & 653 & 2.39 & 0.79 & 1 & 3 \\
\hline $\begin{array}{l}\text { Expected duration of impacts for the current COVID-19 } \\
\text { outbreak }\end{array}$ & 653 & 3.42 & 1.08 & 0 & 1 \\
\hline \multicolumn{6}{|l|}{ Individual characteristics } \\
\hline Have a job & 653 & 0.83 & 0.38 & 0 & 1 \\
\hline Self-employed & 653 & 0.11 & 0.32 & 0 & 1 \\
\hline Have a permanent job contract & 653 & 0.56 & 0.50 & 0 & 1 \\
\hline Have a short-term job contract & 653 & 0.15 & 0.36 & 0 & 1 \\
\hline Good health & 653 & 0.64 & 0.48 & 0 & 1 \\
\hline Age 18 to 30 & 653 & 0.17 & 0.38 & 0 & 1 \\
\hline Age 31 to 40 & 653 & 0.37 & 0.48 & 0 & 1 \\
\hline Age 41 to 50 & 653 & 0.39 & 0.49 & 0 & 1 \\
\hline Age 51 to 68 & 653 & 0.07 & 0.25 & 0 & 1 \\
\hline Female & 653 & 0.51 & 0.50 & 0 & 1 \\
\hline Kinh & 653 & 0.98 & 0.13 & 0 & 1 \\
\hline Have a college education & 653 & 0.32 & 0.47 & 0 & 1 \\
\hline Have a graduate education & 653 & 0.61 & 0.49 & 0 & 1 \\
\hline Married & 653 & 0.76 & 0.43 & 0 & 1 \\
\hline Follow no religion & 653 & 0.77 & 0.42 & 0 & 1 \\
\hline Urban & 653 & 0.89 & 0.31 & 0 & 1 \\
\hline
\end{tabular}

Note: A higher value for one's finance or the economy indicate a better situation. The online survey is reweighted using age and gender according to the Labor Force Survey 2020. Source: Own calculations from the survey data.

Worries about job loss after the COVID-19 pandemic are prominent in our sample, with an average score of 1.95 out of the maximal value of 3 . About one-fourth ( 25 percent) of survey individuals report not worrying about their jobs; out of those (75 percent) that are worried about their jobs, 21 percent are very worried (calculations not shown). These 
figures are consistent with the finding in a recent study that economic anxiety increased globally after the arrival of the COVID-19 outbreak [23]. Eighty-three percent of the survey respondents had a job at the interview time, and the majority (86 percent) of those who work are wage earners (calculations not shown).

Regarding changes in current household finance, roughly two-thirds of survey respondents report either less income (66 percent) or less savings (61 percent) because of the impacts of COVID-19. These are represented by the dark blue sections in the two bars in Figure 1. Less than one percent of surveyed individuals could report an increase in income, while around 10 percent report more savings, perhaps in preparation for negative effects of the pandemic in the future. Using transaction-level household financial data in the U.S., [46] also document that household spending sharply declined after some initial increase as the outbreak was spreading. These changes are represented by the light green sections in the bars (Figure 1).

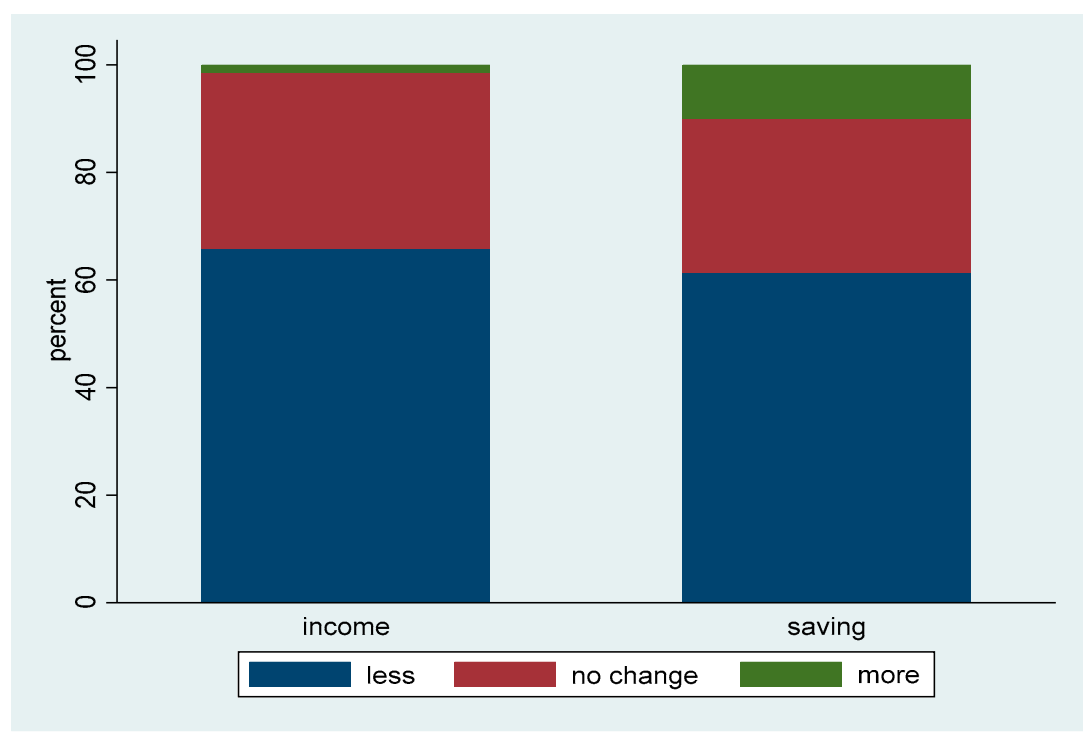

Figure 1. Changes in households' income and savings due to COVID-19, Vietnam 2020. Source: Own calculations from the survey data.

The surveyed respondents, however, are more optimistic about the future. Approximately 35 percent expect their financial situation to improve in the next 3 months, while 28 percent expect the opposite, and the remaining respondents expect no change (Figure 2).

\subsection{Analytical Framework}

We estimate the following Equation

$$
y_{i}=\alpha+\beta^{\prime} j o b_{i}+\gamma^{\prime} x_{i}+\varepsilon_{i}
$$

where $y_{i}$ include three sets of outcome variables for individual $i$, for $i=1, \ldots, \mathrm{N}$. The first set of outcome variables consists of the self-reported financial situation and changes to one's income and saving that individuals attribute to the effects of COVID-19. The (selfreported) financial situation variable has five values ranging from 1 to 5 , which respectively correspond to "very bad", "bad", "average", "good", and "very good". The variables for the changes to one's income and saving have three values ranging from 1 to 3 , indicating whether these changes result in situations that are "worse", "the same", or "better". 


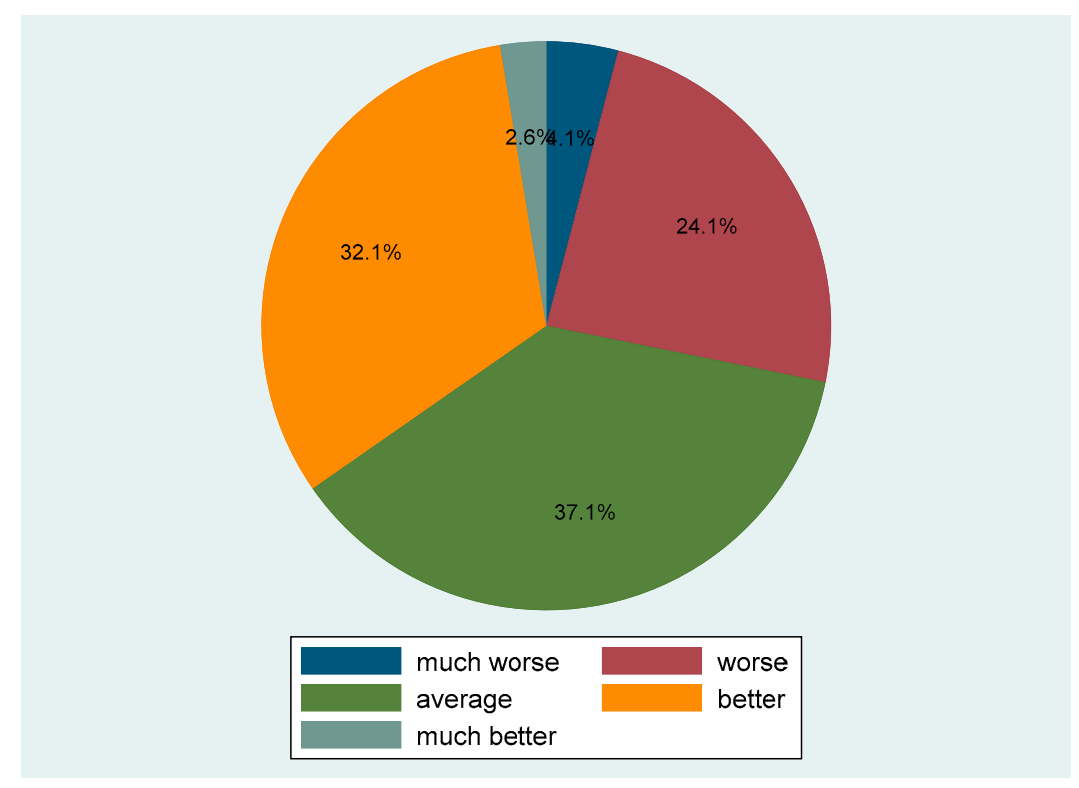

Figure 2. Households' expected financial situation for next 3 months, Vietnam 2020. Source: Own calculations from the survey data.

The second set includes expectations about one's financial situation in the next 3 months and worries about one's job. The variable expectations about one's financial situation in the next 3 months also has five values, which correspond to "much worse", "worse", "no change", "better", and "much better". The variable worries about one's job has three values: "no worries", "somewhat", and "a lot".

The third set includes expectations about the economy's resilience after the COVID19 outbreak, expectations about changes to the economy in the next 3 months, and the expected duration of impacts of COVID-19. Both variables on the expectations about the economy's resilience and its expected changes in the next 3 months have three values, which correspond respectively to "pessimistic", "average", and "optimistic" for the first variable and "worse", "no change", and "better" for the second variable. The variable on the expected duration of impacts consists of the following five values: "under 3 months", " 3 to less than 6 months", "6 months to less than 1 year", " 1 to less than 2 years" and "2 years or more". For all these outcome variables except for worries about one's job and the expected duration of impacts, a higher value indicates a better financial status or a higher level of expectation.

The vector $j o b_{i}$ indicates whether an individual has a job, or whether this individual is self-employed, has a permanent contract or a short-term contract (with the reference group having no labor contract). The key parameters of interest are $\beta$, which capture the relationship of these employment variables with the individual's financial welfare and expectations about the economy. The ability to find (and hold) a job may be correlated with individual unobserved characteristics such as innate ability or interpersonal skills, which can also correlate with the outcome variables. Consequently, we interpret $\beta$ as representing an associational rather than a causal relationship. The vector of control variables $\left(x_{i}\right)$ include age dummy variables, gender, education level, ethnicity, health status, marital status, religion, and urban/rural residence.

For easier interpretation, we estimate Equation (1) with the OLS method so that the estimated pandemic impacts can just be read off of the estimated coefficients. To obtain robust estimates, we offer heteroskedasticity-robust variance estimates of the error term $\varepsilon_{i}$. However, since the outcome variables have a categorical nature, we also offer an alternative modelling option, i.e., the ordered probit model, for robustness check purposes.

The ordered probit model is defined as follows

$$
y_{i}^{*}=\delta^{\prime} j o b_{i}+\theta^{\prime} x_{i}+\tau_{i t}
$$


where $y_{i}=j$ if $\mu_{j-1}<y_{i}^{*}<\mu_{j}$, for $j=0,1, \ldots, J$ and $\mu_{h, h<0}=-\infty, \mu_{0}=0$, and $\mu_{J}=+\infty$. In this model, each value of $j$ represents a discrete value of the outcome variable. For example, the three values of the variable worries about one's job "a lot", "somewhat", and "no worries" respectively correspond to $j=0, j=1$, and $j=2$. The probability of falling into category $j$ is then $P\left(y_{i}=j \mid j o b_{i}, x_{i}\right)=\Phi\left(\mu_{j}-\delta^{\prime} j o b_{i}-\theta^{\prime} x_{i}\right)-\Phi\left(\mu_{j-1}-\delta^{\prime} j o b_{i}-\theta^{\prime} x_{i}\right)$, where $\Phi($.$) is the cdf of the normal distribution. See also [47] or [48] for textbook treatments$ of discrete choice models.

\section{Results}

\subsection{Profiling of Survey Respondents and Their Current Finance}

We provide the estimation results using Equation (1) for the first set of the outcome variables in Table 3. For robustness check, we provide in Table A3 the estimates for Equation (1) using the ordered probit model. Estimation results are qualitatively similar to those shown in Table 2. Estimates using the ordered probit model for Tables 3 and 4 are also qualitatively similar (not shown). Having a job is positively associated with better finance and more income and savings, and this relationship is strongly statistically significant (compared to the reference group with no labor contract). An individual with a job scores 0.4 points higher on their finance evaluation (on a 1 to 5 scale) and 0.2 points higher on their income or savings evaluations (on a 1 to 3 scale) (Table 3, Models 1 to 3 ). These results highlight the importance of employment in having higher living standards.

To gain further insights into the relationship between different types of job and one's current finance, we subsequently disaggregate employment by security levels into self-employment, having a permanent job contract, and having a short-term job contract (with the reference category having no labor contract). All these three types of job are positively and strongly statistically significantly associated with one's financial situation, compared with the reference group of having no contract. Table 3 (Model 4) shows that self-employment is most strongly associated with better finance ( 0.7 points), followed by having a permanent contract ( 0.4 points) and having a short-term contract ( 0.3 points).

Notably, the estimated coefficient for being self-employed is positive and statistically significant for all the three outcomes. This result is perhaps not surprising, since selfemployment is broadly defined to include business owners, family workers, and those in self-employment in general, as discussed earlier. We do not further disaggregate the different employment sub-categories in self-employment because of its small sample size. Having a permanent contract is positively associated with more income, but the estimated coefficient is only marginally statistically significant at the 10 percent level. On the other hand, having a short-term contract is strongly associated with more savings, which is perhaps due to the fact that wage-workers with less job security might save more.

Turning to the other independent variables, those with good health or higher educational levels have positive self-assessments on all three outcome variables. An individual having good health or having a college degree scores 0.4 to 0.5 points higher when evaluating their current finance, which is roughly the same magnitude shown by an individual who has a job (Table 3, Model 1). Having a graduate degree shows a slightly stronger estimated coefficient at 0.8 points higher than other groups. This result concurs with a similar finding for the U.K. and the U.S. that people without a university education were significantly more likely to experience drops in their income due the pandemic [24]. Furthermore, the beneficial impacts of good health as a key component of general economic growth, particularly in mitigating the pandemic, are emphasized in [26]. 
Table 3. Characteristics of individuals that were impacted by COVID-19 and their finance, Vietnam 2020.

\begin{tabular}{|c|c|c|c|c|c|c|}
\hline & Model 1 & Model 2 & Model 3 & Model 4 & Model 5 & Model 6 \\
\hline & $\begin{array}{l}\text { Current } \\
\text { Finance }\end{array}$ & $\begin{array}{l}\text { Income } \\
\text { Change }\end{array}$ & $\begin{array}{l}\text { Saving } \\
\text { Change }\end{array}$ & $\begin{array}{l}\text { Current } \\
\text { Finance }\end{array}$ & $\begin{array}{l}\text { Income } \\
\text { Change }\end{array}$ & $\begin{array}{l}\text { Saving } \\
\text { Change }\end{array}$ \\
\hline Have a job & $\begin{array}{c}0.461^{* * *} \\
(0.14)\end{array}$ & $\begin{array}{c}0.194^{* *} \\
(0.08)\end{array}$ & $\begin{array}{c}0.235^{* * *} \\
(0.08)\end{array}$ & & & \\
\hline Self-employed & & & & $\begin{array}{c}0.725^{* * *} \\
(0.23)\end{array}$ & $\begin{array}{c}0.291 \text { ** } \\
(0.12)\end{array}$ & $\begin{array}{c}0.455^{* * *} \\
(0.17)\end{array}$ \\
\hline Have a permanent contract & & & & $\begin{array}{c}0.422 * * * \\
(0.15)\end{array}$ & $\begin{array}{c}0.174^{*} \\
(0.09)\end{array}$ & $\begin{array}{c}0.155^{*} \\
(0.09)\end{array}$ \\
\hline Have a short-term contract & & & & $\begin{array}{c}0.310^{* *} \\
(0.13)\end{array}$ & $\begin{array}{l}0.164 \\
(0.11)\end{array}$ & $\begin{array}{c}0.233^{* *} \\
(0.11)\end{array}$ \\
\hline Good health & $\begin{array}{c}0.432 * * * \\
(0.10)\end{array}$ & $\begin{array}{l}0.007 \\
(0.06)\end{array}$ & $\begin{array}{l}0.156 * \\
(0.08)\end{array}$ & $\begin{array}{c}0.433^{* * *} \\
(0.10)\end{array}$ & $\begin{array}{l}0.009 \\
(0.06)\end{array}$ & $\begin{array}{c}0.165^{* *} \\
(0.08)\end{array}$ \\
\hline Age from 18 to 30 & $\begin{array}{c}-0.485^{* * *} \\
(0.16)\end{array}$ & $\begin{array}{l}0.145 \\
(0.10)\end{array}$ & $\begin{array}{l}0.189 \\
(0.13)\end{array}$ & $\begin{array}{c}-0.452 * * * \\
(0.16)\end{array}$ & $\begin{array}{l}0.152 \\
(0.09)\end{array}$ & $\begin{array}{l}0.194 \\
(0.13)\end{array}$ \\
\hline Age from 31 to 40 & $\begin{array}{c}-0.376^{* *} \\
(0.15)\end{array}$ & $\begin{array}{l}0.069 \\
(0.08)\end{array}$ & $\begin{array}{l}0.078 \\
(0.12)\end{array}$ & $\begin{array}{c}-0.343^{* *} \\
(0.15)\end{array}$ & $\begin{array}{l}0.084 \\
(0.08)\end{array}$ & $\begin{array}{l}0.118 \\
(0.11)\end{array}$ \\
\hline Age from 41 to 50 & $\begin{array}{c}-0.398^{* * *} \\
(0.16)\end{array}$ & $\begin{array}{c}-0.028 \\
(0.08)\end{array}$ & $\begin{array}{c}-0.059 \\
(0.12)\end{array}$ & $\begin{array}{c}-0.373^{* *} \\
(0.16)\end{array}$ & $\begin{array}{c}-0.016 \\
(0.08)\end{array}$ & $\begin{array}{c}-0.024 \\
(0.11)\end{array}$ \\
\hline Female & $\begin{array}{c}-0.099 \\
(0.11)\end{array}$ & $\begin{array}{c}-0.061 \\
(0.06)\end{array}$ & $\begin{array}{c}-0.045 \\
(0.08)\end{array}$ & $\begin{array}{c}-0.073 \\
(0.10)\end{array}$ & $\begin{array}{c}-0.053 \\
(0.06)\end{array}$ & $\begin{array}{c}-0.031 \\
(0.08)\end{array}$ \\
\hline Kinh & $\begin{array}{c}-0.647 \\
(0.53)\end{array}$ & $\begin{array}{l}-0.42 \\
(0.27)\end{array}$ & $\begin{array}{l}0.141 \\
(0.20)\end{array}$ & $\begin{array}{c}-0.651 \\
(0.51)\end{array}$ & $\begin{array}{c}-0.427 * \\
(0.26)\end{array}$ & $\begin{array}{l}0.107 \\
(0.23)\end{array}$ \\
\hline Have a college education & $\begin{array}{c}0.512 * \\
(0.27)\end{array}$ & $\begin{array}{c}-0.034 \\
(0.11)\end{array}$ & $\begin{array}{c}-0.139 \\
(0.14)\end{array}$ & $\begin{array}{c}0.590 * * \\
(0.28)\end{array}$ & $\begin{array}{c}-0.007 \\
(0.11)\end{array}$ & $\begin{array}{c}-0.079 \\
(0.15)\end{array}$ \\
\hline Have a graduate education & $\begin{array}{c}0.801 \text { *** } \\
(0.28)\end{array}$ & $\begin{array}{l}0.118 \\
(0.12)\end{array}$ & $\begin{array}{l}0.032 \\
(0.15)\end{array}$ & $\begin{array}{c}0.899 * * * \\
(0.30)\end{array}$ & $\begin{array}{l}0.155 \\
(0.12)\end{array}$ & $\begin{array}{l}0.119 \\
(0.17)\end{array}$ \\
\hline Married & $\begin{array}{c}-0.081 \\
(0.11)\end{array}$ & $\begin{array}{c}-0.086 \\
(0.07)\end{array}$ & $\begin{array}{c}-0.132 \\
(0.10)\end{array}$ & $\begin{array}{c}-0.111 \\
(0.11)\end{array}$ & $\begin{array}{c}-0.094 \\
(0.07)\end{array}$ & $\begin{array}{c}-0.141 \\
(0.09)\end{array}$ \\
\hline Follow no religion & $\begin{array}{l}0.023 \\
(0.12)\end{array}$ & $\begin{array}{c}0.02 \\
(0.07)\end{array}$ & $\begin{array}{c}-0.059 \\
(0.10)\end{array}$ & $\begin{array}{l}0.056 \\
(0.12)\end{array}$ & $\begin{array}{c}0.03 \\
(0.07)\end{array}$ & $\begin{array}{c}-0.041 \\
(0.09)\end{array}$ \\
\hline Urban & $\begin{array}{c}-0.156 \\
(0.17)\end{array}$ & $\begin{array}{c}-0.057 \\
(0.09)\end{array}$ & $\begin{array}{c}0.185 \text { * } \\
(0.10)\end{array}$ & $\begin{array}{c}-0.179 \\
(0.17)\end{array}$ & $\begin{array}{c}-0.062 \\
(0.09)\end{array}$ & $\begin{array}{c}0.181 \text { * } \\
(0.10)\end{array}$ \\
\hline Constant & $\begin{array}{c}2.990^{* * *} \\
(0.65)\end{array}$ & $\begin{array}{c}1.629^{* * *} \\
(0.31)\end{array}$ & $\begin{array}{c}1.029^{* * * *} \\
(0.24)\end{array}$ & $\begin{array}{c}2.895^{* * *} \\
(0.60)\end{array}$ & $\begin{array}{c}1.599^{* * *} \\
(0.30)\end{array}$ & $\begin{array}{c}0.975^{* * *} \\
(0.26)\end{array}$ \\
\hline$\sigma$ & 0.779 & 0.492 & 0.65 & 0.773 & 0.492 & 0.645 \\
\hline Adjusted R2 & 0.227 & 0.058 & 0.06 & 0.238 & 0.06 & 0.074 \\
\hline $\mathrm{N}$ & 653 & 653 & 653 & 653 & 653 & 653 \\
\hline
\end{tabular}

Note: ${ }^{*} p<0.1,{ }^{* *} p<0.05,{ }^{* * *} p<0.01$. Robust standard errors are in parentheses. The reference age group is age 51 to 68 . Source: Own calculations from the survey data.

Older individuals unsurprisingly have better finance, as being one age group older is strongly statistically associated with scoring 0.02 points higher (Table 3, Models 1 and 4). Married respondents show lower levels of saving, which can perhaps be caused by a strong need for a higher living standard, but the estimated coefficient is marginally significant at the 10 percent level (Table 3, Models 3 and 6). Ethnicity, religion, and urban/rural residence do not have a statistically significantly relationship with one's current finance or changes to income and savings. 
Table 4. Expectations about own financial situation for next 3 months, Vietnam 2020.

\begin{tabular}{ccccc}
\hline & Model 1 & Model 2 & Model 3 & Model 4 \\
\cline { 2 - 5 } & $\begin{array}{c}\text { Expected } \\
\text { Finance }\end{array}$ & Job Worry & $\begin{array}{c}\text { Expected } \\
\text { Finance }\end{array}$ & Job Worry \\
\hline Have a job & -0.14 & $-0.321^{* * *}$ & & \\
Self-employed & $(0.15)$ & $(0.11)$ & & \\
& & & 0.332 & -0.126 \\
Have a permanent contract & & & $(0.22)$ & $(0.17)$ \\
Have a short-term contract & & -0.242 & $-0.392^{* * *}$ \\
& & & $(0.16)$ & $(0.12)$ \\
$\sigma$ & 0.884 & 0.629 & -0.277 & $-0.323^{* * *}$ \\
Adjusted R2 & 0.056 & 0.134 & $(0.18)$ & $(0.125)$ \\
N & 653 & 653 & 0.868 & 0.625 \\
& & & 0.089 & 0.144 \\
\hline
\end{tabular}

Note: ${ }^{* * *} p<0.01$. Robust standard errors are in parentheses. Other control variables are not shown to save space. The full regression results are provided in Appendix B, Table A1. Source: Own calculations from the survey data.

\subsection{Expectations for the Future}

Table 4 provides estimates for the respondents' expectations about their own financial situations and job prospects in the next 3 months. We only show job-related variables in this table for a more focused discussion; the full regression results are provided in Appendix B, Table A1. While individuals with a job tend to have lower expectations for their future finance (Table 4, Model 1), they have fewer worries about their job (Table 4, Model 2). However, only the latter result is statistically significant. This latter result holds for both types of wage workers, regardless of the type of contract, but is not statistically significant for the self-employed (Table 4, Model 4). Understandably, those with a job contract can be far less worried about their job prospects than those who have no job contract, scoring 0.3 to 0.4 points less worried (on a 1 to 3 scale). Given the stable nature of their job contracts, the former group of workers are well protected under Vietnam's current labor code and social insurance law. Self-employed individuals are somewhat more optimistic about their future finance, but this is not statistically significant (Table 4, Model 3).

In Table 5, we further examine individuals' expectations about the resilience of the economy, the economy prospects in the next 3 months, as well as the expected duration of the outbreak impacts. Full regression results are shown in Appendix B, Table A2. Having a job is statistically significant and positively correlated with better assessments for the economy resilience, but has no statistically significant relationship with assessments of the economy prospects in the next 3 months, or the expected duration of the outbreak impacts (Table 5, Models 1 to 3). These results generally hold for all the three types of employment (Table 5, Models 4 to 6). The only exception is that those with a permanent contract expect the pandemic impacts to last longer, but the estimated coefficient is marginally statistically significant at the 10 percent level (Table 5, Model 6). To some extent, these results appear consistent with [31]'s finding that Chinese individuals with a (more secure) government job have more confidence in the economy. These results may also be indirectly consistent with [14]'s findings for the U.S. that the perceived unemployment rate is higher in lockdown counties which have a higher unemployment rate.

Regarding other characteristics, older individuals and individuals in the Kinh ethnic major group tend to have less optimistic assessments for their financial situation in the next 3 months, while married individuals tend to have more job worries (Appendix B, Table A1). The finding that women in Vietnam tend to have more pessimistic expectations for their future financial situations is consistent with recent evidence for other richer countries [25], but the estimated coefficient is marginally statistically significant in our case. Older and more educated individuals appear to be less confident about the economy resilience and expect the COVID-19 pandemic impacts to last longer, while those in good health or in the Kinh ethnic major group are more optimistic (Table A2). The latter finding is in line with 
recent evidence indicating that racial minorities in OECD countries and the U.S. are more adversely affected by the pandemic [27].

Table 5. Expectations about the economy, Vietnam 2020.

\begin{tabular}{|c|c|c|c|c|c|c|}
\hline & Model 1 & Model 2 & Model 3 & Model 4 & Model 5 & Model 6 \\
\hline & $\begin{array}{l}\text { Economy } \\
\text { Resilience }\end{array}$ & $\begin{array}{c}\text { Economy } \\
\text { during Next } 3 \\
\text { Months }\end{array}$ & $\begin{array}{l}\text { Expected } \\
\text { Duration of } \\
\text { Impacts }\end{array}$ & $\begin{array}{l}\text { Economy } \\
\text { Resilience }\end{array}$ & $\begin{array}{c}\text { Economy } \\
\text { during Next } \\
3 \text { Months }\end{array}$ & $\begin{array}{c}\text { Expected } \\
\text { Duration of } \\
\text { Impacts }\end{array}$ \\
\hline Have a job & $\begin{array}{c}0.347^{* * *} \\
(0.10)\end{array}$ & $\begin{array}{l}0.047 \\
(0.12)\end{array}$ & $\begin{array}{l}0.295 \\
(0.21)\end{array}$ & & & \\
\hline Self-employed & & & & $\begin{array}{c}0.365^{* *} \\
(0.17)\end{array}$ & $\begin{array}{c}-0.016 \\
(0.22)\end{array}$ & $\begin{array}{l}0.496 \\
(0.30)\end{array}$ \\
\hline Have a permanent & & & & $0.346^{* * *}$ & 0.134 & $0.382 *$ \\
\hline & & & & $(0.11)$ & $(0.14)$ & $(0.22)$ \\
\hline $\begin{array}{l}\text { Have a short-term } \\
\text { contract }\end{array}$ & & & & $0.336^{* *}$ & -0.078 & -0.015 \\
\hline & & & & $(0.14)$ & $(0.15)$ & $(0.22)$ \\
\hline$\sigma$ & 0.664 & 0.781 & 1.048 & 0.665 & 0.778 & 1.04 \\
\hline Adjusted R2 & 0.072 & 0.03 & 0.059 & 0.07 & 0.036 & 0.073 \\
\hline $\mathrm{N}$ & 653 & 653 & 653 & 653 & 653 & 653 \\
\hline
\end{tabular}

Note: ${ }^{*} p<0.1,{ }^{* *} p<0.05,{ }^{* * *} p<0.01$. Robust standard errors are in parentheses. Other control variables are not shown to save space. The full regression results are provided in Appendix B, Table A2. Source: Own calculations from the survey data.

\section{Further Discussion}

Our results highlight the importance of jobs, and job security, in improving individuals' current finance and evaluations of their future finance and the economy. This is consistent with recent evidence that creating formal and decent jobs is a first-best employment policy $[49,50]$. Furthermore, since consumer confidence can boost consumption spending and help build a stronger economy [18,19], our findings suggest that policies that create good jobs can have multiple layers of positive effects for the post-outbreak period. For those that are self-employed, it appears that policies that can provide access to business opportunities (which can help reduce their work worries) may be more important.

Our findings also suggest that those who are more vulnerable (such as people with lower educational levels, in worse health, or without a labor contract) might be more affected by the COVID-19 pandemic. In particular, workers in the informal sector, including migrant workers, usually have no labor contract and have unstable jobs without social protection benefits. Under the COVID-19-induced lockdown, these individuals were likely to suffer more income loss given the nature of their work. These findings are consistent with recommendations to protect vulnerable workers during the pandemic from international organizations including ILO, UNICEF, and the World Bank [51-53].

Indeed, the current lockdowns in major cities across Vietnam caused by the delta variant surge since late April $2021[54,55]$ further highlight the vulnerabilities of these workers. Southern cities are reported to have accounted for $80 \%$ of coronavirus deaths and the Government of Vietnam has brought in troops to better enforce lockdown and deliver food in Ho Chi Minh City, the largest city in the country [56,57]. Stories abound in the media that many vulnerable migrant workers in the major cities, who lost their job because of the pandemic, fell into economically precarious situations because of the lockdowns [58-61]. More worrisomely, these vulnerable workers are likely to be at more health risks than the general population.

To further examine this hypothesis for policy advice, we collected data on the pandemic current death rates and infection rates for the first half of August 2021 from [62]. The death rate is defined as the number of deaths divided by the number of infected people, and the infection rate is defined as the number of infected people divided by the population. Both these rates are expressed in percent. We further combined these data with the most 
recent labor data from the 2020 LFS and the population data from the 2019 Population and Housing Census, which provide estimates on the total number of vulnerable works in each province (or major cities). We then plotted in Figure 3 the infection rates and death rates against the number of the vulnerable workers at the province level.

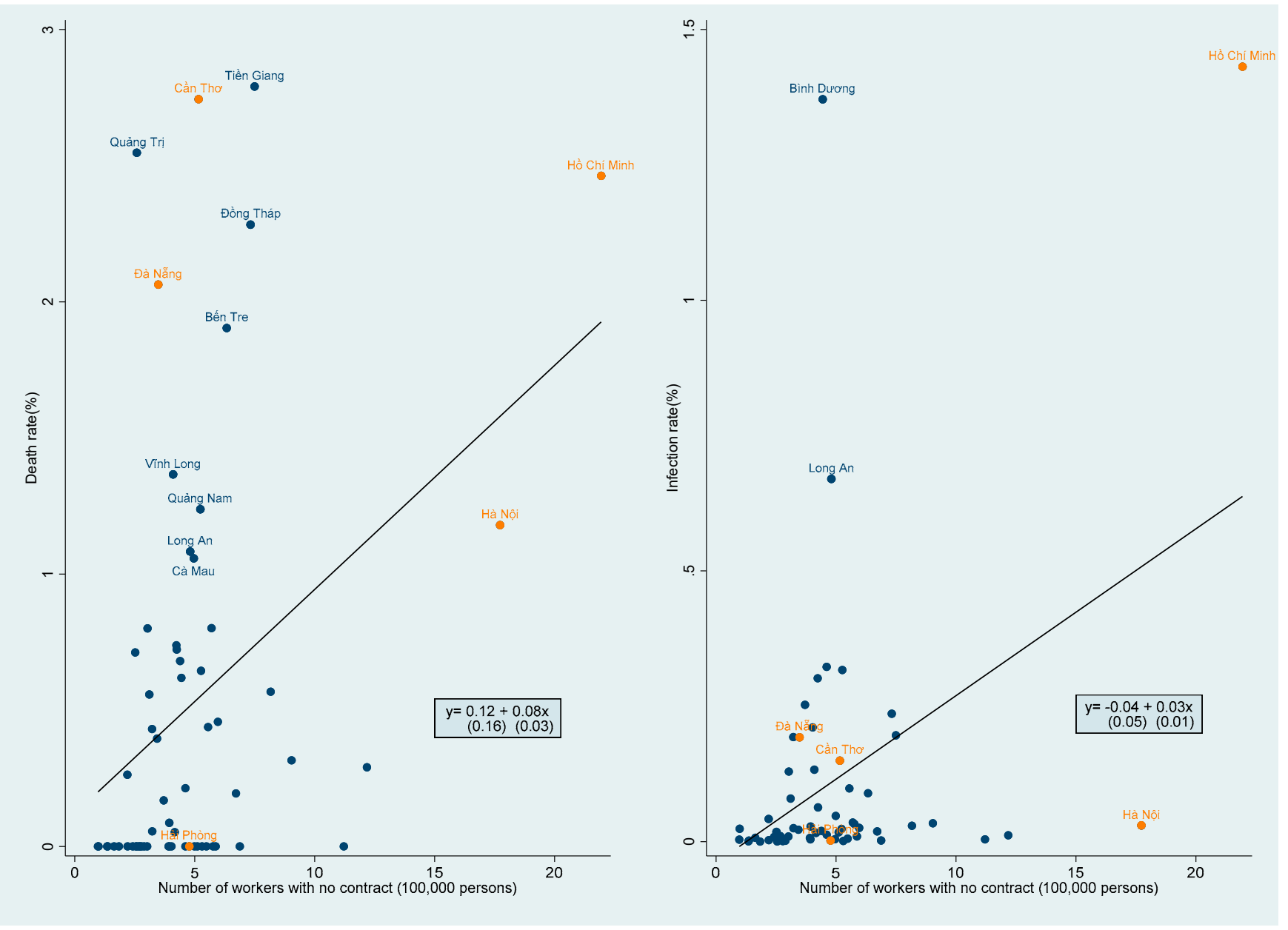

Figure 3. Death rate and infection rate versus number of workers without a contract, Vietnam 2021.

This figure shows a positive and strongly statistically significant correlation between these variables. On average, a 100,000-person increase in the number of vulnerable workers is associated with a 0.08 percentage point increase in the death rates (left panel) and a 0.03 percentage point increase in the infection rates (right panel) (these figures are obtained from the OLS regressions of the rate on a dummy variable and the number of vulnerable workers as shown in the boxes inside the graphs). The major cities in central and southern Vietnam, including Ho Chi Minh City, Cantho, and Danang (shown in orange) especially have higher death rates compared to their numbers of vulnerable workers. These results emphasize the double benefits of providing assistance to these vulnerable workers, which can improve their economic welfare and public health outcomes at the same time.

We also find that those with higher education achievements have more positive assessments of their current finance, which concurs with recent evidence for the US and the UK $[24,63]$. While we also find that more educated individuals appear less optimistic about the future, this result does not detract from the values of education in securing a better financial position. As such, besides job policies, education policies can also take an important role in shielding individuals against the harmful financial effects of COVID-19. On the other hand, it perhaps does not come as a surprise that individuals in good health are found to have more positive evaluations for their current and future finance. 
Our estimation results point to little gender difference in the pandemic's impacts, which is reassuringly corroborated by similar results based on in-depth analysis of multiple rounds of the LFS [12]. However, we also find some indicative evidence suggesting that women in Vietnam tend to have more pessimistic expectations for their future financial situations.

We acknowledge that given the nature of an online rapid assessment survey, our survey sample size is small and does not cover certain population groups such as informal workers. Yet, compared to a large-scale household survey that typically takes more than a year to complete, the key advantage of implementing the online rapid assessment survey is that it can provide fast and just-in-time data collection. Most importantly, despite these potential non-coverage issues, the online rapid assessment survey helps provide timely inputs into policies to fight against the pandemic. This has been acknowledged for medical studies on serosurveillance by [37], as discussed earlier. Furthermore, to correct potential sampling bias, we reweighted the survey using the Labor Force Survey (LFS) in 2020-the official source for labor statistics in the country. We also provided further comparison with qualitatively similar findings from studies in richer countries.

A promising direction for future research is thus to improve on the sampling frame to collect more data on informal workers (who may be left out even in surveys with a much larger sample size). Other fruitful directions are to collect more disaggregated data on different occupation sectors and geographical regions that can help us better disentangle potential heterogeneous effects across these categories.

\section{Conclusions}

We implemented the first web-based rapid assessment survey in Vietnam to collect data on individuals' assessments of their current and future financial situations and the general economy immediately after the country relaxed its lockdown policy near the end of April 2020. We find that having a job is strongly and positively associated with better finance and more income and savings, and more optimism about the resilience of the economy. Further disaggregating employment into different types of jobs such as self-employment and jobs with permanent and short-term contracts, we find those with permanent job contracts have fewer job worries and better assessments for the economy. Individuals with good health tend to have more positive evaluations for their current and future finance, but there are mixed results for those with higher education levels.

In summary, the results based on our early assessment of the pandemic's negative effects, particularly on individual expectations of their own finance and the economy, can provide useful and much needed inputs for policy makers in designing various economic policies. These policies could range from social protection measures that immediately ameliorate the pandemic's short-term economic and health impacts to post-outbreak policies that invest in education and stimulate longer-term economic growth. Yet, our results also suggest that these policies should be tailor made to serve different population groups, such as vulnerable workers or women, to maximize their impacts. This is relevant not only for Vietnam but perhaps also other poorer countries, particularly as the pandemic is still ongoing in many countries around the world.

Author Contributions: H.-A.H.D. supervised data analysis, drafted, and finalized the article; L.T.G. was in charge of data collection and contributed to drafting the article; M.N.N.D. implemented final data analysis. The final version was completed and agreed by all authors. All authors have read and agreed to the published version of the manuscript.

Funding: This research was funded by the UK Foreign, Commonwealth and Development Office through a Knowledge for Change (KCP) grant for the World Development Report 2021.

Institutional Review Board Statement: IRB No.02/HDDD-ISMS, dated 4 March 2020 by the Institute of Social and Medical Studies (ISMS).

Informed Consent Statement: Not applicable. 
Data Availability Statement: Data are available upon reasonable request.

Acknowledgments: We would like to thank the editor Daniel Zhang, three anonymous reviewers, and Viet-Cuong Nguyen for useful feedback on earlier versions.

Conflicts of Interest: The authors declare no conflict of interest. The funders had no role in the design of the study; in the collection, analyses, or interpretation of data; in the writing of the manuscript, or in the decision to publish the results.

\section{Appendix A. Part of the Web-based Rapid Assessment Survey Questionnaire Related to Jobs, Finance, and Expectations}

\begin{tabular}{|c|c|c|c|c|}
\hline A & PERSONAL INFORMATION & & & \\
\hline 1 & Year of birth & & & \\
\hline \multirow[t]{3}{*}{2} & Sex & & & \\
\hline & & Male & 1 & \\
\hline & & Female & 2 & \\
\hline \multirow[t]{3}{*}{3} & Ethnicity & & & \\
\hline & & Kinh & 1 & \\
\hline & & Other (detail) & 99 & \\
\hline \multirow[t]{3}{*}{4} & Permanent living place (for more than & in the past 12 months) & & \\
\hline & & Urban & 1 & \\
\hline & & Rural & 2 & \\
\hline \multirow[t]{9}{*}{5} & Highest educational level & & & \\
\hline & & Never go to school & 1 & \\
\hline & & Incomplete primary school & 2 & \\
\hline & & Complete primary school & 3 & \\
\hline & & Complete secondary school & 4 & \\
\hline & & Complete upper-secondary school & 5 & \\
\hline & & College/University & 6 & \\
\hline & & Postgraduate (Master, $\mathrm{PhD}$ ) & 7 & \\
\hline & & Other (detail) & 99 & \\
\hline \multirow[t]{6}{*}{6} & Marital status & & & \\
\hline & & Currently married & 1 & \\
\hline & & Never married & 2 & \\
\hline & & Separated & 3 & \\
\hline & & Divorced & 4 & \\
\hline & & Widow & 5 & \\
\hline \multirow[t]{3}{*}{7} & Are you the household head? & & & \\
\hline & & Yes & 1 & \\
\hline & & No & 2 & \\
\hline \multirow[t]{9}{*}{8} & Religion & & & \\
\hline & & No religion & 0 & \\
\hline & & Buddhism & 1 & \\
\hline & & Christian & 2 & \\
\hline & & Protestant & 3 & \\
\hline & & Hoa Hao & 4 & \\
\hline & & Cao Dai & 5 & \\
\hline & & Islamic & 6 & \\
\hline & & Other (detail) & 99 & \\
\hline \multirow[t]{3}{*}{9} & Did you work during the past 14 days? & & & \\
\hline & & Yes & 1 & \\
\hline & & No & 2 & Skipped to A12 \\
\hline
\end{tabular}


10 If yes, your work position was ...

11 What is the type of your work contract?

$$
\begin{array}{rr}
\text { Business owner } & 1 \\
\text { Self-employed } & 2 \\
\text { Family business worker } & 3 \\
\text { Cooperative's member } & 4 \\
\text { Wage worker } & 5
\end{array}
$$

12 What are the reasons that you do not have work now?

Labor contract of 3 months or less 1 Labor contract of 3 months to less than 12 months 2

Labor contract of 1 year to 3 years 3

Permanent labor contract 4

Project-based labor contract 5

By verbal agreement 6

No labor contract $\quad 7$

12

Have not found a job yet $\quad 1$

Waiting for a new job 2

Due to business closures under COVID-19 3

Due to recent health problems 4

Due to personal/family matter 5

Other (detail)___ $\quad 99$

13 What is your household's poverty status?

$\begin{array}{rr}\text { Non-poor } & 1 \\ \text { Poor or near-poor } & 2 \\ \text { Yes, mandatory } & 1 \\ \text { Yes, voluntary } & 2 \\ \text { No } & 3\end{array}$

19 In the past 14 days, how did you feel about your health?

$\begin{array}{rr}\text { Good } & 1 \\ \text { Normal } & 2 \\ \text { Not good } & 3\end{array}$

\section{B SELF-ASSESSMENT OF COVID-19'S IMPACTS ON SOCIO-ECONOMIC LIFE}

1 What do you think about our economy's resilience after COVID-19?

2 What do you think about the current status of the economy?

$\begin{array}{rr}\text { Optimistic } & 1 \\ \text { Normal } & 2 \\ \text { Pessimistic } & 3\end{array}$

$\begin{aligned} \text { Good } & 1 \\ \text { Normal } & 2 \\ \text { Bad } & 3\end{aligned}$

3 What do you expect the economy to be in the next 3 month?

In your opinion, how long will the COVID-19's impacts on the economy last? 
5 What is your assessment of your household's current financial situation?

$\begin{aligned} \text { Good } & 1 \\ \text { Fairly good } & 2 \\ \text { Normal } & 3 \\ \text { Fairly bad } & 4 \\ \text { Bad } & 5\end{aligned}$

6

How would you expect your household's financial situation to change in the next 3 months?

$7 \quad$ How did your household's income change due to COVID-19?

Much better $\quad 1$

A little better $\quad 2$

Unchanged 3

A little worse $\quad 4$

Much worse $\quad 5$

(

How did your household's expenditure change due to COVID-19?

$\begin{array}{rr}\text { Increased } & 1 \\ \text { Unchanged } & 2 \\ \text { Decreased } & 3\end{array}$

8 How did your household's expenditure change due to COVID-19?

$9 \quad$ How did your household's savings change due to COVID-19?

$\begin{array}{rr}\text { Increased } & 1 \\ \text { Unchanged } & 2 \\ \text { Decreased } & 3\end{array}$

$\begin{array}{rr}\text { Increased } & 1 \\ \text { Unchanged } & 2 \\ \text { Decreased } & 3\end{array}$

$10 \quad$ How do you worry about your job because of COVID-19?

$\begin{aligned} \text { Very worried } & 1 \\ \text { A little worried } & 2 \\ \text { No worried } & 3\end{aligned}$

\section{Appendix B. Additional Tables}

Table A1. Expectations about Own Financial Situation for Next 3 Months, Vietnam 2020.

\begin{tabular}{|c|c|c|c|c|}
\hline & Model 1 & Model 2 & Model 3 & Model 4 \\
\hline & Expected Finance & Job Worry & Expected Finance & Job Worry \\
\hline Have a job & $\begin{array}{l}-0.14 \\
(0.15)\end{array}$ & $\begin{array}{c}-0.321^{* * *} \\
(0.11)\end{array}$ & & \\
\hline Self-employed & & & $\begin{array}{l}0.332 \\
(0.22)\end{array}$ & $\begin{array}{c}-0.126 \\
(0.17)\end{array}$ \\
\hline Have a permanent contract & & & $\begin{array}{c}-0.242 \\
(0.16)\end{array}$ & $\begin{array}{c}-0.392^{* * * *} \\
(0.12)\end{array}$ \\
\hline Have a short-term contract & & & $\begin{array}{c}-0.277 \\
(0.18)\end{array}$ & $\begin{array}{c}-0.323^{* *} \\
(0.13)\end{array}$ \\
\hline Good health & $\begin{array}{l}0.085 \\
(0.12)\end{array}$ & $\begin{array}{c}-0.101 \\
(0.08)\end{array}$ & $\begin{array}{l}0.096 \\
(0.11)\end{array}$ & $\begin{array}{c}-0.092 \\
(0.09)\end{array}$ \\
\hline Age from 18 to 30 & $\begin{array}{l}0.312 \\
(0.21)\end{array}$ & $\begin{array}{c}0.375 * * * \\
(0.13)\end{array}$ & $\begin{array}{c}0.347^{*} \\
(0.21)\end{array}$ & $\begin{array}{c}0.380 * * * \\
(0.13)\end{array}$ \\
\hline Age from 31 to 40 & $\begin{array}{c}0.322 * * \\
(0.15)\end{array}$ & $\begin{array}{c}0.16 \\
(0.13)\end{array}$ & $\begin{array}{c}0.394^{* *} \\
(0.16)\end{array}$ & $\begin{array}{l}0.195 \\
(0.13)\end{array}$ \\
\hline Age from 41 to 50 & $\begin{array}{l}0.072 \\
(0.16)\end{array}$ & $\begin{array}{c}0.322 * * \\
(0.13)\end{array}$ & $\begin{array}{l}0.132 \\
(0.16)\end{array}$ & $\begin{array}{c}0.354^{* * *} \\
(0.13)\end{array}$ \\
\hline Female & $\begin{array}{c}-0.190 * \\
(0.12)\end{array}$ & $\begin{array}{c}-0.138 \text { * } \\
(0.08)\end{array}$ & $\begin{array}{c}-0.151 \\
(0.12)\end{array}$ & $\begin{array}{c}-0.125 \\
(0.08)\end{array}$ \\
\hline Kinh & $\begin{array}{c}-0.875 * * * \\
(0.33)\end{array}$ & $\begin{array}{l}0.166 \\
(0.34)\end{array}$ & $\begin{array}{c}-0.913^{* * *} \\
(0.30)\end{array}$ & $\begin{array}{l}0.136 \\
(0.37)\end{array}$ \\
\hline
\end{tabular}


Table A1. Cont.

\begin{tabular}{|c|c|c|c|c|}
\hline & Model 1 & Model 2 & Model 3 & Model 4 \\
\hline & Expected Finance & Job Worry & Expected Finance & Job Worry \\
\hline \multirow[t]{2}{*}{ Have a college education } & 0.296 & -0.071 & 0.43 & -0.017 \\
\hline & $(0.28)$ & $(0.23)$ & $(0.29)$ & $(0.22)$ \\
\hline \multirow[t]{2}{*}{ Have a graduate education } & 0.144 & -0.302 & 0.324 & -0.225 \\
\hline & $(0.28)$ & $(0.25)$ & $(0.29)$ & $(0.24)$ \\
\hline \multirow[t]{2}{*}{ Married } & 0.173 & 0.154 * & 0.136 & 0.146 \\
\hline & $(0.18)$ & $(0.09)$ & $(0.17)$ & (0.09) \\
\hline \multirow[t]{2}{*}{ Follow no religion } & -0.081 & 0.042 & -0.033 & 0.057 \\
\hline & $(0.14)$ & $(0.10)$ & $(0.13)$ & $(0.10)$ \\
\hline \multirow[t]{2}{*}{ Urban } & -0.085 & -0.047 & -0.109 & -0.05 \\
\hline & $(0.18)$ & (0.14) & (0.17) & (0.14) \\
\hline \multirow[t]{2}{*}{ Constant } & $3.722 * * *$ & $2.095 * * *$ & $3.580 * * *$ & $2.046^{* * *}$ \\
\hline & $(0.46)$ & $(0.39)$ & $(0.42)$ & $(0.43)$ \\
\hline$\sigma$ & 0.884 & 0.629 & 0.868 & 0.625 \\
\hline Adjusted R2 & 0.056 & 0.134 & 0.089 & 0.144 \\
\hline $\mathrm{N}$ & 653 & 653 & 653 & 653 \\
\hline
\end{tabular}

Note: ${ }^{*} p<0.1,{ }^{* *} p<0.05,{ }^{* * *} p<0.01$. Robust standard errors are in parentheses. The reference age group is age 51 to 68 .

Table A2. Expectations about the Economy, Vietnam 2020.

\begin{tabular}{|c|c|c|c|c|c|c|}
\hline & Model 1 & Model 2 & Model 3 & Model 4 & Model 5 & Model 6 \\
\hline & $\begin{array}{l}\text { Economy's } \\
\text { Resilience }\end{array}$ & $\begin{array}{l}\text { Economy } \\
\text { during Next } \\
3 \text { Months }\end{array}$ & $\begin{array}{l}\text { Expected } \\
\text { Duration of } \\
\text { Impacts }\end{array}$ & $\begin{array}{l}\text { Economy's } \\
\text { Resilience }\end{array}$ & $\begin{array}{l}\text { Economy } \\
\text { during Next } \\
3 \text { Months }\end{array}$ & $\begin{array}{l}\text { Expected } \\
\text { Duration of } \\
\text { Impacts }\end{array}$ \\
\hline Have a job & $\begin{array}{c}0.347^{* * *} \\
(0.10)\end{array}$ & $\begin{array}{l}0.047 \\
(0.12)\end{array}$ & $\begin{array}{l}0.295 \\
(0.21)\end{array}$ & & & \\
\hline Self-employed & & & & $\begin{array}{c}0.365^{* *} \\
(0.17)\end{array}$ & $\begin{array}{c}-0.016 \\
(0.22)\end{array}$ & $\begin{array}{l}0.496 \\
(0.30)\end{array}$ \\
\hline Have a permanent contract & & & & $\begin{array}{c}0.346^{* * *} \\
(0.11)\end{array}$ & $\begin{array}{l}0.134 \\
(0.14)\end{array}$ & $\begin{array}{l}0.382 * \\
(0.22)\end{array}$ \\
\hline Have a short-term contract & & & & $\begin{array}{c}0.336^{* *} \\
(0.14)\end{array}$ & $\begin{array}{c}-0.078 \\
(0.15)\end{array}$ & $\begin{array}{c}-0.015 \\
(0.22)\end{array}$ \\
\hline Good health & $\begin{array}{c}0.162 * * \\
(0.08)\end{array}$ & $\begin{array}{c}0.289 * * * \\
(0.11)\end{array}$ & $\begin{array}{c}-0.185 \\
(0.15)\end{array}$ & $\begin{array}{c}0.162 * \\
(0.08)\end{array}$ & $\begin{array}{c}0.278^{* *} \\
(0.11)\end{array}$ & $\begin{array}{c}-0.198 \\
(0.14)\end{array}$ \\
\hline Age from 18 to 30 & $\begin{array}{l}0.164 \\
(0.16)\end{array}$ & $\begin{array}{l}0.061 \\
(0.17)\end{array}$ & $\begin{array}{c}-0.512 \text { ** } \\
(0.23)\end{array}$ & $\begin{array}{l}0.166 \\
(0.16)\end{array}$ & $\begin{array}{l}0.081 \\
(0.17)\end{array}$ & $\begin{array}{c}-0.453^{* *} \\
(0.23)\end{array}$ \\
\hline Age from 31 to 40 & $\begin{array}{c}0.19 \\
(0.12)\end{array}$ & $\begin{array}{l}0.069 \\
(0.14)\end{array}$ & $\begin{array}{l}-0.28 \\
(0.19)\end{array}$ & $\begin{array}{c}0.192 * \\
(0.12)\end{array}$ & $\begin{array}{l}0.045 \\
(0.14)\end{array}$ & $\begin{array}{c}-0.275 \\
(0.19)\end{array}$ \\
\hline Age from 41 to 50 & $\begin{array}{l}0.067 \\
(0.12)\end{array}$ & $\begin{array}{l}-0.15 \\
(0.15)\end{array}$ & $\begin{array}{c}-0.103 \\
(0.20)\end{array}$ & $\begin{array}{l}0.068 \\
(0.12)\end{array}$ & $\begin{array}{c}-0.175 \\
(0.15)\end{array}$ & $\begin{array}{c}-0.106 \\
(0.20)\end{array}$ \\
\hline Female & $\begin{array}{l}0.115 \\
(0.08)\end{array}$ & $\begin{array}{c}0.16 \\
(0.10)\end{array}$ & $\begin{array}{l}-0.05 \\
(0.14)\end{array}$ & $\begin{array}{l}0.117 \\
(0.08)\end{array}$ & $\begin{array}{l}0.163 \\
(0.10)\end{array}$ & $\begin{array}{c}-0.019 \\
(0.14)\end{array}$ \\
\hline Kinh & $\begin{array}{c}0.320^{* *} \\
(0.15)\end{array}$ & $\begin{array}{l}0.127 \\
(0.32)\end{array}$ & $\begin{array}{l}-0.14 \\
(0.53)\end{array}$ & $\begin{array}{c}0.320^{* *} \\
(0.15)\end{array}$ & $\begin{array}{l}0.167 \\
(0.30)\end{array}$ & $\begin{array}{c}-0.093 \\
(0.50)\end{array}$ \\
\hline Have a college education & $\begin{array}{c}-0.455^{* * *} \\
(0.15)\end{array}$ & $\begin{array}{c}-0.172 \\
(0.19)\end{array}$ & $\begin{array}{c}0.576 \text { * } \\
(0.34)\end{array}$ & $\begin{array}{c}-0.450 \\
(0.15)\end{array}$ & $\begin{array}{c}-0.185 \\
(0.19)\end{array}$ & $\begin{array}{c}0.642 \text { * } \\
(0.33)\end{array}$ \\
\hline Have a graduate education & $\begin{array}{c}-0.599 * * * \\
(0.15)\end{array}$ & $\begin{array}{c}-0.211 \\
(0.19)\end{array}$ & $\begin{array}{l}0.406 \\
(0.36)\end{array}$ & $\begin{array}{c}-0.592^{* * *} \\
(0.15)\end{array}$ & $\begin{array}{c}-0.241 \\
(0.20)\end{array}$ & $\begin{array}{l}0.472 \\
(0.36)\end{array}$ \\
\hline Married & $\begin{array}{r}0.143 \\
(0.12)\end{array}$ & $\begin{array}{l}0.069 \\
(0.13)\end{array}$ & $\begin{array}{c}0.07 \\
(0.18)\end{array}$ & $\begin{array}{l}0.141 \\
(0.12)\end{array}$ & $\begin{array}{l}0.056 \\
(0.14)\end{array}$ & $\begin{array}{c}0.023 \\
(0.17)\end{array}$ \\
\hline Follow no religion & $\begin{array}{l}0.138 \\
(0.10)\end{array}$ & $\begin{array}{c}-0.091 \\
(0.12)\end{array}$ & $\begin{array}{c}-0.015 \\
(0.17)\end{array}$ & $\begin{array}{c}0.14 \\
(0.10)\end{array}$ & $\begin{array}{c}-0.087 \\
(0.13)\end{array}$ & $\begin{array}{l}0.025 \\
(0.17)\end{array}$ \\
\hline Urban & $\begin{array}{l}0.013 \\
(0.11)\end{array}$ & $\begin{array}{l}0.069 \\
(0.14)\end{array}$ & $\begin{array}{l}0.071 \\
(0.23)\end{array}$ & $\begin{array}{l}0.011 \\
(0.11)\end{array}$ & $\begin{array}{l}0.054 \\
(0.14)\end{array}$ & $\begin{array}{l}0.029 \\
(0.22)\end{array}$ \\
\hline Constant & $\begin{array}{c}1.522^{* * *} \\
(0.21)\end{array}$ & $\begin{array}{l}2.100^{* * *} \\
(0.41)\end{array}$ & $\begin{array}{c}3.130 * * * \\
(0.66)\end{array}$ & $\begin{array}{c}1.516^{* * *} \\
(0.22)\end{array}$ & $\begin{array}{c}2.091^{* * *} \\
(0.40)\end{array}$ & $\begin{array}{c}3.020^{* * * *} \\
(0.63)\end{array}$ \\
\hline$\sigma$ & 0.664 & 0.781 & 1.048 & 0.665 & 0.778 & 1.04 \\
\hline Adjusted R2 & 0.072 & 0.03 & 0.059 & 0.07 & 0.036 & 0.073 \\
\hline $\mathrm{N}$ & 653 & 653 & 653 & 653 & 653 & 653 \\
\hline
\end{tabular}


Table A3. Characteristics of Individuals that Were Impacted by COVID-19 and Their Finance Using an Ordered Probit Model, Vietnam 2020.

\begin{tabular}{|c|c|c|c|c|c|c|}
\hline & Model 1 & Model 2 & Model 3 & Model 4 & Model 5 & Model 6 \\
\hline & $\begin{array}{l}\text { Current } \\
\text { Finance }\end{array}$ & $\begin{array}{l}\text { Income } \\
\text { Change }\end{array}$ & $\begin{array}{l}\text { Saving } \\
\text { Change }\end{array}$ & $\begin{array}{l}\text { Current } \\
\text { Finance }\end{array}$ & $\begin{array}{l}\text { Income } \\
\text { Change }\end{array}$ & $\begin{array}{l}\text { Saving } \\
\text { Change }\end{array}$ \\
\hline Have a job & $\begin{array}{c}0.680 * * * \\
(0.20)\end{array}$ & $\begin{array}{c}0.589 * * \\
(0.27)\end{array}$ & $\begin{array}{c}0.534^{* * *} \\
(0.20)\end{array}$ & & & \\
\hline Self-employed & & & & $\begin{array}{c}1.028^{* * *} \\
(0.32)\end{array}$ & $\begin{array}{c}0.850^{* *} \\
(0.35)\end{array}$ & $\begin{array}{c}0.941^{* * *} \\
(0.31)\end{array}$ \\
\hline Have a permanent contract & & & & $\begin{array}{c}0.660 * * * \\
(0.21)\end{array}$ & $\begin{array}{c}0.547^{* *} \\
(0.28)\end{array}$ & $\begin{array}{c}0.391 \text { * } \\
(0.21)\end{array}$ \\
\hline Have a short-term contract & & & & $\begin{array}{c}0.480^{* *} \\
(0.20)\end{array}$ & $\begin{array}{l}0.508 \\
(0.31)\end{array}$ & $\begin{array}{c}0.522 * * \\
(0.24)\end{array}$ \\
\hline Good health & $\begin{array}{c}0.626^{* * *} \\
(0.14)\end{array}$ & $\begin{array}{l}0.004 \\
(0.16)\end{array}$ & $\begin{array}{l}0.299 * \\
(0.16)\end{array}$ & $\begin{array}{c}0.638^{* * *} \\
(0.14)\end{array}$ & $\begin{array}{l}0.007 \\
(0.16)\end{array}$ & $\begin{array}{c}0.319^{* *} \\
(0.16)\end{array}$ \\
\hline Age from 18 to 30 & $\begin{array}{c}-0.727^{* * *} \\
(0.23)\end{array}$ & $\begin{array}{l}0.411 \text { * } \\
(0.25)\end{array}$ & $\begin{array}{l}0.375 \\
(0.24)\end{array}$ & $\begin{array}{c}-0.695^{* * *} \\
(0.23)\end{array}$ & $\begin{array}{l}0.444 \text { * } \\
(0.25)\end{array}$ & $\begin{array}{c}0.403 \text { * } \\
(0.24)\end{array}$ \\
\hline Age from 31 to 40 & $\begin{array}{c}-0.513^{* *} \\
(0.21)\end{array}$ & $\begin{array}{l}0.204 \\
(0.22)\end{array}$ & $\begin{array}{l}0.153 \\
(0.22)\end{array}$ & $\begin{array}{c}-0.480 * * \\
(0.22)\end{array}$ & $\begin{array}{l}0.248 \\
(0.22)\end{array}$ & $\begin{array}{l}0.241 \\
(0.21)\end{array}$ \\
\hline Age from 41 to 50 & $\begin{array}{c}-0.553^{* *} \\
(0.22)\end{array}$ & $\begin{array}{c}-0.062 \\
(0.22)\end{array}$ & $\begin{array}{c}-0.095 \\
(0.23)\end{array}$ & $\begin{array}{c}-0.529 * * \\
(0.22)\end{array}$ & $\begin{array}{c}-0.025 \\
(0.22)\end{array}$ & $\begin{array}{c}-0.017 \\
(0.21)\end{array}$ \\
\hline Female & $\begin{array}{c}-0.089 \\
(0.15)\end{array}$ & $\begin{array}{c}-0.153 \\
(0.15)\end{array}$ & $\begin{array}{c}-0.091 \\
(0.15)\end{array}$ & $\begin{array}{l}-0.06 \\
(0.15)\end{array}$ & $\begin{array}{c}-0.128 \\
(0.15)\end{array}$ & $\begin{array}{c}-0.056 \\
(0.15)\end{array}$ \\
\hline Kinh & $\begin{array}{c}-0.9 \\
(0.72)\end{array}$ & $\begin{array}{c}-0.898 \\
(0.56)\end{array}$ & $\begin{array}{l}0.245 \\
(0.40)\end{array}$ & $\begin{array}{c}-0.899 \\
(0.69)\end{array}$ & $\begin{array}{c}-0.926^{*} \\
(0.54)\end{array}$ & $\begin{array}{c}0.13 \\
(0.43)\end{array}$ \\
\hline Have a college education & $\begin{array}{c}0.789 \text { ** } \\
(0.38)\end{array}$ & $\begin{array}{c}-0.059 \\
(0.34)\end{array}$ & $\begin{array}{c}-0.223 \\
(0.34)\end{array}$ & $\begin{array}{c}0.890 * * \\
(0.39)\end{array}$ & $\begin{array}{l}0.031 \\
0.33)\end{array}$ & $\begin{array}{c}-0.085 \\
(0.35)\end{array}$ \\
\hline Have a graduate education & $\begin{array}{c}1.242 * * * \\
(0.39)\end{array}$ & $\begin{array}{c}0.37 \\
(0.37)\end{array}$ & $\begin{array}{l}0.099 \\
(0.35)\end{array}$ & $\begin{array}{c}1.372^{* * *} \\
(0.40)\end{array}$ & $\begin{array}{l}0.487 \\
(0.36)\end{array}$ & $\begin{array}{l}0.299 \\
(0.37)\end{array}$ \\
\hline Married & $\begin{array}{c}-0.156 \\
(0.16)\end{array}$ & $\begin{array}{c}-0.221 \\
(0.18)\end{array}$ & $\begin{array}{c}-0.231 \\
(0.17)\end{array}$ & $\begin{array}{c}-0.199 \\
(0.16)\end{array}$ & $\begin{array}{c}-0.242 \\
(0.18)\end{array}$ & $\begin{array}{c}-0.254 \\
(0.17)\end{array}$ \\
\hline Follow no religion & $\begin{array}{l}0.025 \\
(0.16)\end{array}$ & $\begin{array}{l}0.071 \\
(0.18)\end{array}$ & $\begin{array}{c}-0.143 \\
(0.19)\end{array}$ & $\begin{array}{l}0.067 \\
(0.17)\end{array}$ & $\begin{array}{l}0.098 \\
(0.18)\end{array}$ & $\begin{array}{c}-0.103 \\
(0.18)\end{array}$ \\
\hline Urban & $\begin{array}{c}-0.231 \\
(0.25)\end{array}$ & $\begin{array}{c}-0.169 \\
(0.25)\end{array}$ & $\begin{array}{c}0.374 \text { * } \\
(0.22)\end{array}$ & $\begin{array}{c}-0.263 \\
(0.25)\end{array}$ & $\begin{array}{l}-0.18 \\
(0.25)\end{array}$ & $\begin{array}{l}0.371 \\
(0.23)\end{array}$ \\
\hline$\mu_{1}$ & $\begin{array}{c}-1.884^{* *} \\
(0.89)\end{array}$ & $\begin{array}{l}0.043 \\
(0.68)\end{array}$ & $\begin{array}{c}1.282^{* * *} \\
(0.49)\end{array}$ & $\begin{array}{c}-1.770 \\
(0.84)\end{array}$ & $\begin{array}{l}0.146 \\
(0.65)\end{array}$ & $\begin{array}{c}1.388^{* * *} \\
(0.51)\end{array}$ \\
\hline$\mu_{2}$ & $\begin{array}{c}-0.835 \\
(0.88)\end{array}$ & $\begin{array}{c}1.964^{* * *} \\
(0.70)\end{array}$ & $\begin{array}{c}2.342^{* * *} \\
(0.49)\end{array}$ & $\begin{array}{c}-0.723 \\
(0.83)\end{array}$ & $\begin{array}{c}2.079 * * * \\
(0.67)\end{array}$ & $\begin{array}{c}2.463^{* * *} \\
(0.51)\end{array}$ \\
\hline$\mu_{3}$ & $\begin{array}{l}1.172 \\
(0.88)\end{array}$ & & & $\begin{array}{l}1.296 \\
(0.84)\end{array}$ & & \\
\hline$\mu_{4}$ & $\begin{array}{c}1.847^{* *} \\
(0.89)\end{array}$ & & & $\begin{array}{c}1.984^{* *} \\
(0.84)\end{array}$ & & \\
\hline Log likelihood & -687.58 & -431.38 & -552.35 & -683.07 & -429.65 & -546.47 \\
\hline Chi2 & 85.306 & 30.058 & 33.085 & 87.075 & 32.507 & 39.982 \\
\hline $\mathrm{N}$ & 653 & 653 & 653 & 653 & 653 & 653 \\
\hline
\end{tabular}

Note: ${ }^{*} p<0.1,{ }^{* *} p<0.05,{ }^{* * *} p<0.01$. Robust standard errors are in parentheses. The reference age group is age 51 to 68 . Estimates are obtained using an ordered probit model.

\section{References}

1. Belot, M.; Syngjoo, C.; Julian, C.J.; Nicholas, W.P.; Egon, T.; van den Broek-Altenburg, E. Six-Country Survey on COVID-19; IZA Discussion Paper No. 13230; IZA Institute of Labor Economics: Bonn, Germany, 2020.

2. Our World in Data, Vietnam: Coronavirus Pandemic Country Profile. 2021. Available online: https://ourworldindata.org/ coronavirus/country/vietnam\#citation (accessed on 5 August 2021).

3. Huynh, T.L.D. The COVID-19 containment in Vietnam: What are we doing? J. Glob. Health 2020, 10, 010338. [CrossRef]

4. La, P.V.; Pham, H.T.; Ho, T.M.; Nguyen, H.M.; Nguyen, L.P.K.; Vuong, T.T.; Tran, T.; Khuc, Q.; Ho, T.M.; Vuong, H.Q. Policy Response, Social Media and Science Journalism for the Sustainability of the Public Health System amid the COVID-19-19 Outbreak: The Vietnam Lessons. Sustainability 2020, 12, 2931. [CrossRef] 
5. Trevisan, M.; Le, L.C.; Le, A.V. The COVID-19 Pandemic: A View from Vietnam. Am. J. Public Health 2020, 110, 1152-1153. [CrossRef]

6. Dinh, L.; Dinh, P.; Nguyen, P.D.; Nguyen, D.H.; Hoang, T. Vietnam's response to COVID-19: Prompt and proactive actions. J. Travel Med. 2020, 1-3. [CrossRef] [PubMed]

7. Tam, L.T.; Ho, H.X.; Nguyen, D.P.; Elias, A.; Le, A.N.H. Receptivity of governmental communication and its effectiveness during COVID-19 pandemic emergency in Vietnam: A qualitative study. Glob. J. Flex. Syst. Manag. 2021, 22, 45-64. [CrossRef]

8. Nguyen, T.V.; Dai Tran, Q.; Phan, L.T.; Vu, L.N.; Truong, D.T.T.; Truong, H.C.; Pham, Q.D. In the interest of public safety: Rapid response to the COVID-19 epidemic in Vietnam. BMJ Global Health 2021, 6, e004100. [CrossRef] [PubMed]

9. Reed, J.; Chung, H.P. Vietnam's coronavirus offensive wins praise for low-cost model. Financial Times, 23 March 2020.

10. Mandhana, N.; Lam, L. Some Countries Are Squashing the Coronavirus Curve. Vietnam Is One. Wall Street Journal, 27 April 2020.

11. Nguyen, H.K. Vietnam's Low-Cost COVID-19 Strategy. Project Syndicate, 8 April 2020.

12. Dang, H.-A.; Nguyen, C.V. Did a Successful Fight Against the COVID-19 Pandemic Come at a Cost? Impacts of the Outbreak on Employment Outcomes in Vietnam; IZA Discussion Paper No. 13958; IZA Institute of Labor Economics: Bonn, Germany, 2020.

13. National Economics University (NEU). Report on the Impacts of the COVID-19 Pandemic on the Economy and Policy Response Recommendations (in Vietnamese); National Economics University: Hanoi, Vietnam, 2020.

14. Coibion, O.; Gorodnichenko, Y.; Weber, M. The Cost of the Covid-19 Crisis: Lockdowns, Macroeconomic Expectations, and Consumer Spending (No. w27141); National Bureau of Economic Research: Cambridge, MA, USA, 2020. [CrossRef]

15. Bailey, M.; Dávila, E.; Kuchler, T.; Stroebel, J. House price beliefs and mortgage leverage choice. Rev. Econ. Stud.. 2019, 86, 2403-2452. [CrossRef]

16. D'Acunto, F.; Hoang, D.; Weber, M. Managing Households' Expectations with Unconventional Policies (No. w27399); National Bureau of Economic Research: Cambridge, MA, USA, 2020. [CrossRef]

17. Kuchler, T.; Zafar, B. Personal experiences and expectations about aggregate outcomes. J. Financ. 2019, 74, 2491-2542. [CrossRef]

18. Carroll, C.D.; Fuhrer, J.C.; Wilcox, D.W. Does consumer sentiment forecast household spending? If so, why? Am. Econ. Rev. 1994, 84, 1397-1408.

19. Roth, C.; Wohlfart, J. How do expectations about the macroeconomy affect personal expectations and behavior? Rev. Econ. Stat. 2019, 102, 731-748. [CrossRef]

20. Gallagher, J. Learning about an infrequent event: Evidence from Flood Insurance Take-Up in the United States. Am. Econ. J. Appl. Econ. 2014, 6, 206-233. [CrossRef]

21. Rabin, M. Inference by believers in the law of small numbers. Q. J. Econ. 2002, 117, 775-816. [CrossRef]

22. Binder, C. Coronavirus fears and macroeconomic expectations. Rev. Econ. Stat. 2020, 102, 721-730. [CrossRef]

23. Fetzer, T.; Lukas, H.; Johannes, H.; Chris, R. Coronavirus Perceptions and Economic Anxiety. Rev. Econ. Stat. 2020, 1-36. [CrossRef]

24. Adams-Prassl, A.; Teodora, B.; Marta, G.; Christopher, R. Inequality in the impact of the coronavirus shock: Evidence from real time surveys. J. Public Econ. 2021. [CrossRef]

25. Dang, H.-A.; Nguyen, C.V. Gender inequality during the COVID-19 pandemic: Income, expenditure, savings, and job loss. World Dev. 2021, 140, 105296. [CrossRef]

26. Bloom, D.E.; Kuhn, M.; Prettner, K. Modern Infectious Diseases: Macroeconomic Impacts and Policy Responses. J. Econ. Literature 2020. [CrossRef]

27. Brodeur, A.; Gray, D.; Islam, A.; Bhuiyan, S. A literature review of the economics of COVID-19. J. Econ. Surv. 2021, 35, 1007-1044. [CrossRef]

28. Hanspal, T.; Weber, A.; Wohlfart, J. Exposure to the COVID-19 stock market crash and its effect on household expectations. Rev. Econ. Stat. 2020, 1-45. [CrossRef]

29. Alon, T.; Coskun, S.; Doepke, M.; Koll, D.; Tertilt, M. From Mancession to Shecession: Women's Employment in Regular and Pandemic Recessions (No. w28632); National Bureau of Economic Research: Cambridge, MA, USA, 2021. [CrossRef]

30. BRAC. Rapid Perception Survey On COVID19 Awareness and Economic Impact. 2020. Available online: https:/ / reliefweb.int/ report/bangladesh/rapid-perception-survey-covid19-awareness-and-economic-impact-final-draft (accessed on 20 May 2020).

31. Ho, J.; Aimee, K.; Naomi, Y. Survey: Asian Consumer Sentiment during the COVID-19 Crisis. McKinsey \& Company Report. 2020. Available online: https:/ / www.mckinsey.com/featured-insights/asia-pacific/survey-asian-consumer-sentiment-duringthe-covid-19-crisis (accessed on 20 May 2020).

32. Bui, D.; Bernd, H.; Giang, N.; Lena, D. Consumer Sentiment during the COVID-19 Pandemic: The Role of Others' Beliefs; CESifo Working Paper No. 9010; CESifo: Munich, Germany, 2021.

33. Yue, P.; Gizem Korkmaz, A.; Zhou, H. Household financial decision making amidst the COVID-19 pandemic. Emerg. Mark. Financ. Trade 2020, 56, 2363-2377. [CrossRef]

34. Evans, J.R.; Mathur, A. The value of online surveys. Internet Res. 2005, 15, 195-219. [CrossRef]

35. Callegaro, M.; Manfreda, K.L.; Vehovar, V. Web Survey Methodology; Sage: London, UK, 2015.

36. Vehovar, V.; Toepoel, V.; Steinmetz, S. Non-probability sampling. The Sage Handbook of Survey Methods; SAGE Publications: Thousand Oaks, CA, USA, 2016; pp. 329-345.

37. Brown, T.S.; Walensky, R.P. Serosurveillance and the COVID-19 epidemic in the US: Undetected, uncertain, and out of control. Jama 2020, 32, 749-751. [CrossRef] [PubMed] 
38. Eysenbach, G. Improving the Quality of Web Surveys: The Checklist for Reporting Results of Internet E-Surveys (CHERRIES). J. Med. Internet Res. 2004, 6, e132. [CrossRef]

39. Barrafrem, K.; Västfjäll, D.; Tinghög, G. Financial well-being, COVID-19, and the financial better-than-average-effect. J. Behav. Exp. Financ. 2020, 28, 100410. [CrossRef] [PubMed]

40. Brown, S.M.; Doom, J.R.; Lechuga-Pena, S.; Watamura, S.O.; Koppels, T. Stress and parenting during the global COVID-19 pandemic. Child Abus. Negl. 2020, 110, 104699. [CrossRef] [PubMed]

41. Mgammal, M.H.; Al-Matari, E.M. Survey data of coronavirus (COVID-19) thought concern, employees work performance, employees background, feeling about job, work motivation, job satisfaction, psychological state of mind and family commitment in two middle east countries. Data Brief 2021, 34, 106661. [CrossRef]

42. Gesser-Edelsburg, A.; Cohen, R.; Hijazi, R.; Shahbari, N.A.E. Analysis of public perception of the Israeli government's early emergency instructions regarding COVID-19: Online survey study. J. Med. Internet Res. 2020, 22, e19370. [CrossRef] [PubMed]

43. Lippens, L.; Moens, E.; Sterkens, P.; Weytjens, J.; Baert, S. How do employees think the COVID-19 crisis will affect their careers? PLoS ONE 2021, 16, e0246899. [CrossRef] [PubMed]

44. Pacifico, D. sreweight: A Stata command to reweight survey data to external totals. Stata J. 2014, 14, 4-21. [CrossRef]

45. Deville, J.C.; Särndal, C.E. Calibration estimators in survey sampling. J. Am. Stat. Assoc. 1992, 87, 376-382. [CrossRef]

46. Baker, S.R.; Farrokhnia, R.A.; Meyer, S.; Pagel, M.; Yannelis, C. How Does Household Spending Respond to an Epidemic? Consumption during the 2020 COVID-19 Pandemic; National Bureau of Economic Research Working Paper No. 26949; National Bureau of Economic Research: Cambridge, MA, USA, 2020.

47. Long, J.S. Regression Models for Categorical and Limited Dependent Variables; SAGE Publications: Thousand Oaks, CA, USA, 1997.

48. Greene, W.H. Econometric Analysis, 8th ed.; Pearson Education: North York, ON, Canada, 2019.

49. World Bank. World Development Report 2019: The Changing Nature of Work; World Bank: Washington, DC, USA, 2019.

50. International Labor Organization. Decent Work. Available online: https://www.ilo.org/global/topics/decent-work/lang--en/ index.htm (accessed on 25 May 2020).

51. International Labor Organization (ILO). COVID-19 and the Labour Market in Viet Nam. Policy Brief. 2020. Available online: https:/ / www.ilo.org/hanoi/Whatwedo/Publications/WCMS_742134/lang--en/index.htm (accessed on 25 August 2021).

52. UNICEF. Rapid Assessment on the Social and Economic Impacts of Covid-19 on Children and Families in Viet Nam. 2020. Available online: https:/ / www.unicef.org/eap/media/6506/file/Impact\%20of\%20COVID-19\%20on\%20children\%20in \%20 Viet\%20Nam.pdf (accessed on 25 August 2021).

53. World Bank. COVID-19 Policy Response Notes for Vietnam; World Bank: Hanoi, Vietnam, 2020; Available online: https:// openknowledge.worldbank.org/handle/10986/33998 (accessed on 25 August 2021).

54. Paddock Richard, C.; Doan, C. Spared for Months, Vietnam Faces a Wave of New Infections. 2021. Available online: https: //www.nytimes.com/2021/06/02/world/asia/vietnam-covid-ho-chi-minh.html (accessed on 21 August 2021).

55. Strangio, S. COVID-19 Stages Another Comeback in Vietnam. 2021. Available online: https://thediplomat.com/2021/05/covid19-stages-another-comeback-in-vietnam/ (accessed on 21 August 2021).

56. Reuters. Vietnam's Biggest Cities Tighten Restrictions as COVID-19 Cases Surge. 2021. Available online: https:/ /www.reuters. com/world/asia-pacific/vietnams-ho-chi-minh-city-extends-virus-lockdown-aug-1-2021-07-23/ (accessed on 21 August 2021).

57. Washington Post. Vietnam Calls on Army for Food Delivery Ahead of Lockdown. 2021. Available online: https: //www.washingtonpost.com/politics/vietnam-calls-on-army-for-food-delivery-ahead-of-lockdown/2021/08/21/e64cda26023b-11ec-87e0-7e07bd9ce270_story.html (accessed on 21 August 2021).

58. Chieu, H. Livelihoods gone, Hanoi's Migrant Workers Bear the Brunt of Lockdown Woes. 2021. Available online: https://e. vnexpress.net/news/life/trend/livelihoods-gone-hanoi-s-migrant-workers-bear-the-brunt-of-lockdown-woes-4338231.html (accessed on 21 August 2021).

59. Dinh, V.; Ha, A. Migrant Workers Stranded in HCMC Fear Financial Ruin Amid Extended Social Distancing. 2021. Available online: https:/ / e.vnexpress.net/news/life/trend/migrant-workers-stranded-in-hcmc-fear-financial-ruin-amid-extended-socialdistancing-4341749.html (accessed on 21 August 2021).

60. Reuters. Workers Try to Flee Vietnam's Biggest City as Coronavirus Crisis Worsens. 2021. Available online: https://www. reuters.com/world/asia-pacific/workers-try-flee-vietnams-biggest-city-coronavirus-crisis-worsens-2021-08-16/ (accessed on 21 August 2021).

61. Tran, Q.; Dinh, V. No way home: Migrants Stuck in HCMC Amid Lockdown. 2021. Available online: https:/ /e.vnexpress.net/ photo/news/no-way-home-migrants-stuck-in-hcmc-amid-lockdown-4341383.html (accessed on 21 August 2021).

62. Ministry of Health. Data and News on Covid-19. 2021. Available online: https://ncov.moh.gov.vn/ (accessed on 21 August 2021).

63. Béland, L.P.; Brodeur, A.; Wright, T. The Short-Term Economic Consequences of COVID-19: Exposure to Disease, Remote Work and Government Response; IZA Discussion Paper No. 13159; IZA Institute of Labor Economics: Bonn, Germany, 2020. 